\title{
Journal of Cardiovascular Magnetic

\section{Cocaine-induced myocardial injury identified as multiple mid-wall foci of enhancement by contrast-enhanced cardiac MRI and large troponin rise Stefan Buchholz*1, Gemma A Figtree ${ }^{1,2}$ and Stuart Grieve ${ }^{2}$}

Address: ${ }^{1}$ Royal North Shore Hospital, Sydney, Australia and ${ }^{2}$ North Shore Heart Research Group, Kolling Institute, Sydney, Australi
${ }^{*}$ Corresponding author

from 13th Annual SCMR Scientific Sessions

Phoenix, AZ, USA. 21-24 January 2010

Published: 21 January 2010

Journal of Cardiovascular Magnetic Resonance 20 I0, I2(SuppI I):PI I4 doi:I0.I I86/I532-429X-I2-SI-PI I4

This abstract is available from: http://jcmr-online.com/content/I2/SI/PI I4

(C) 2010 Buchholz et al; licensee BioMed Central Ltd.

A 26-year-old man with no relevant medical history was admitted with severe retrosternal chest pain. There were no associated symptoms, and no relationship of the pain to inspiration, exertion or posture. It transpired that he infrequently inhaled heroin and cocaine, and also used oral ecstasy tablets, the latter two substances 3 days prior to presentation. He also smoked at least a pack of cigarettes per day. Results of initial cardiac enzyme tests revealed a creatine kinase level of $710 \mathrm{U} / \mathrm{L}$ (normal range $40-300 \mathrm{U} / \mathrm{L}$ ) and troponin I of $10.3 \mu \mathrm{g} / \mathrm{L}$ (normal range $<0.14 \mu \mathrm{g} / \mathrm{L}$ ) which rapidly returned to baseline after the resolution of his pain. 12-lead electrocardiogram showed sinus rhythm with right ventricular conduction delay. Biphasic T-waves were present infero-laterally, suggestive of myocardial ischaemia. Computed tomography of the coronary and pulmonary arteries was unremarkable. Cardiac magnetic resonance imaging (CMRI) was performed and demonstrated normal left ventricular function with no evidence of regional wall motion abnormality and an ejection fraction of 55\%. However, there were multiple foci of mid-wall and subepicardial late enhancement (LE) in the apical septum and apical lateral wall (figure 1). There was no pericardial effusion.

There are multiple potential causes of myocardial injury in conjunction with cocaine use. The character and temporal pattern of the pain in conjunction with sharp rise of troponin, and multiple mid-wall foci of late enhancement on CMRI is suggestive of infarction related to cocaineinduced vasoconstriction of coronary arterioles which

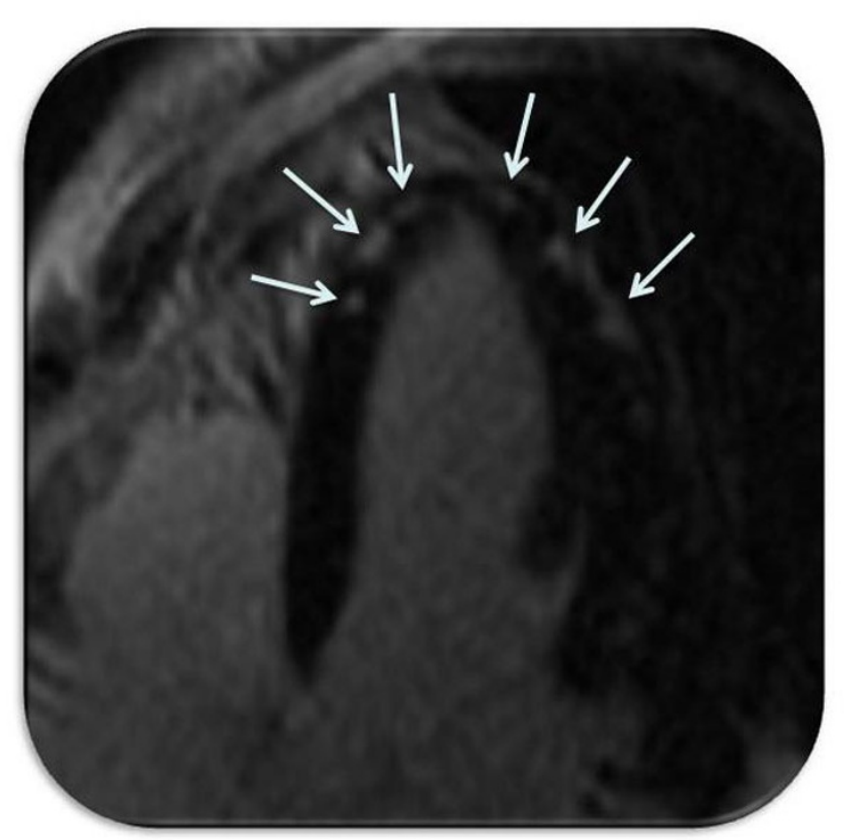

Figure I

Late gadolinium enhanced imaging identifying multiple mid-wall and subepicardial foci (arrows) of myocardial injury (8 minutes after administration of $\mathbf{0 . 2}$ $\mathrm{mmol} / \mathrm{kg}$ body weight of gadopentate dimeglumine; performed on I.5-T General Electric MRI Scanner). 
may have been exacerbated by concomitant increase in platelet aggregation and adrenergic drive. Although alternative diagnoses of myocarditis, or more chronic conditions such as sarcoidosis, arrhythmogenic right ventricular dysplasia, or cardiomyopathy were considered in light of the LE, this was less consistent with the presentation.

Publish with Bio Med Central and every scientist can read your work free of charge

"BioMed Central will be the most significant development for disseminating the results of biomedical research in our lifetime. " Sir Paul Nurse, Cancer Research UK

Your research papers will be:

- available free of charge to the entire biomedical community

- peer reviewed and published immediately upon acceptance

- cited in PubMed and archived on PubMed Central

- yours - you keep the copyright

Submit your manuscript here:

http://www.biomedcentral.com/info/publishing_adv.asp 